\title{
SEASONAL VARIATIONS, PREVALENCE AND INTENSITY OF HELMINTH PARASITES OF SOME FRESHWATER FISH IN ISMAILIA CANAL, EGYPT
}

\author{
By \\ RANIA GAMAL TAHA \\ Department of Biological and Geological Sciences, Faculty of Education, Ain-Shams \\ University, Cairo, Egypt (Dr.Raniagamal_bio@yahoo.com)
}

\begin{abstract}
The present study was conducted to investigate the parasitic infection of 120 samples of three freshwater fish species collected from Ismailia Canal, branch of the River Nile, Northern Cairo, Egypt. The African catfish Clarias gariepinus, the silver catfish Bagrus bajad and the Nile perch Lates niloticus (each species 40 specimens) were studied parasitologically during the whole year of 2017. The results revealed that (47.5\%) of all samples were infected with helminthes. Six helminth species were recorded; One trematode Orientocreadium batrachoides Tubangui, 1931, one cestode Polyonchobothrium clarias Woodland, 1925, three nematodes; Procamallanus sp., Capillaria sp. and Philonema onchorhynchi KuitunenEkbaum, 1933 and one anthocephalan Polymorphus sp. The examination of hosts indicated that $C$. gariepinus had the highest infection rate (55\%) followed by (45\%) and (42.5\%) for $L$. niloticus and B. bajad respectively. Intensity (I), infection index (IX) and the condition factor $(\mathrm{K})$ of the infected hosts were determined. The relationship between the infection and host's sex and size (weight and length) was detected and discussed. Also, a special reference to the effect of seasonal variations on the abundance of infection was estimated. Results were analyzed using SPSS 0.16 for Windows.
\end{abstract}

Key words: Ismailia Canal, Fish, Prevalence, Seasonal variations.

\section{Introduction}

Sector of fish wealth is one of the main important sectors of the Egyptian national economy with an annual production of 76.76 tons (AOAD, 2003). They are the most popular and important organisms for good quality proteins and fatty acids that have an essential role in the health of human body (Debanth, 2011). Parasitism still considered an important factor for causing morbidity and mortality all over the world resulting heavy economic loss (Khanum et al, 2015). It increased greatly in aquatic polluted areas, it has harm effect on the health status of fish, their nutritive value and also their reproductive capacity. In Egypt, the two main sources of potable water supply are groundwater and surface water either from the River Nile and/or main irrigation canals. All sources facing a high rising in pollution basically from discharging industrial and domestic wastewater and return drainage of irrigated water despite all programs for pollution control (Shamrukh and Abdel-Wahab, 2011). Ismailia Canal is one of the most important resources of water for drinking, irrigation and other uses for aquatic life utilizations for a great number of individuals those live in areas of the northern part of Cairo such as Shubra, El-Amiria, Abbasa and Musturod (Geriesh et al. 2008). Many authors stated that Ismailia Canal is very polluted aquatic area due to the presence of heavy metals and inorganic materials for industrial, agricultural and municipal discharges and these pollutants have adverse effects on water quality and aquatic organisms (Stahl and Ramadan, 2008; Ibrahim et al, 2009; 2014). Rivers and lakes are the end point of pollutants discharge that increased aquatic diseases (Elnwishy et al, 2007). Pollution leads diseases agents prevalence, which may be lethal or sub-lethal on fauna (Sures, 2008), growth rate and fish reproduction (Adeyemo and Falaye, 2007; Sabri et al, 2010).

\section{Materials and Methods}

Study area: Ismailia Canal starting from the Nile next to Shubra, North of Cairo and reaching the Suez Canal at Ismailia province as it divides into two branches, one to Suez and the other to Port Said. The length of this canal is $294.35 \mathrm{Km}$. and the average of its 
water depth is $2.8 \mathrm{~m}$. The discharge of water in this canal reached $7 \times 10^{6} \mathrm{~m}^{3} \mathrm{~s}^{-1}$ as indicated by Ministry of Water Resources and Irrigation (MWRI).

A total number of 120 specimens of a freshwater fish, Clarias gariepinus, Lates niloticus and Bagrus bajad were collected from Ismailia Canal, Shubra area, Northern Cairo, Egypt during the period from January to December 2017. The specimens were transferred to the laboratory of Faculty of Education, Ain Shams University. Fish identification was based on the taxonomic work of Schultz (2003). Sex, standard length (SL) and total weight (TW) to nearest $0.1 \mathrm{~cm}$ and $0.1 \mathrm{gm}$ of each specimen was obtained.

Parasitological examination: Samples were immediately dissected and alimentary canal and other internal organs were removed, washed several times in normal saline solution and cut into parts for parasite recovery.

Microscopy and Mounting: Nematodes were fixed in hot $70 \%$ ethanol and preserved in $10 \%$ glycerin and then they cleared in lac- tophenol. The recovered trematodes and cestodes were totally stretched with few drops of $70 \%$ ethyl alcohol between slide and a thin glass cover. The specimens washed very well with distilled water and then each specimen was stained in Acetic Acid Alum Carmine for 5-10 minutes (Stoskoff, 1992). The specimens were differentiated by $1 \%$ Acidic alcohol, dehydrated by using ascending series of ethyl alcohol: 70\%, 80\%, 90\%, 95\% and absolute ethyl alcohol for about 4-5 minutes at each concentration. Clearing of the specimens was made by clove oil and mounted in Canada balsam. According to acanthocephalans, they were dehydrated in series of ethyl alcohols 70, 80, 90, 100 each change for 10 minutes then they cleared in xylol and mounted in Canada balsam.

Parasites were identified according to the standard keys (Yamaguti, 1958; 1961a,b, 1963;Gibson et al, 2002; Amin et al, 2009). Prevalence, mean intensity and abundance were calculated (Margolis et al, 1982):

$$
\begin{gathered}
\begin{array}{c}
\text { Prevalence }=\text { No. of infected fish } \times 100 \\
\text { Total no. of examined fish } \\
\text { Abundance }=\text { No. of parasites } \\
\text { Total no. of examined fish } \\
\text { Mean intensity }=\text { No. of parasites } \\
\text { Total no. of infected fish }
\end{array} \\
\text { Infestation index (IX) was calculated (Bari et al, 2015): } \\
\frac{\text { No. of infected host x no. of parasites }}{(\text { No. of host examined })^{2}}
\end{gathered}
$$

Condition Factor $(\mathrm{K})$ was calculated (Bakare, 1970) as: $\mathrm{K}=100 \mathrm{~W} / \mathrm{L}^{3}$ where $\mathrm{W}=$ the host weight and $\mathrm{L}=$ total length.

Statistical analysis: Standard statistics was carried out using Microsoft Excel (Office 2016). The relationship between the infection rate and sex of the host was determined statistically by One-Way ANOVA (SPSS, 16.0 for Windows), while the influence of host's weight on the prevalence of infection was statistically measured using correlation analysis and paired samples test. A KruskalWalis $(\mathrm{K}-\mathrm{W})$ test was applied to determine the significant differences between parasite mean intensity and season of collection.

\section{Results}

A total number of 207 parasitic helminthes were isolated from 120 examined fish (57 males \& 63 females) of three species; Clarias gariepinus, Lates niloticus and Bagrus bajad. 57/120 samples (47.5\%) were found infected by helminthes. The discovered parasites are of six species; Orientocreadium batrachoides Tubangui, 1931 (trematode), Polyonchobothrium clarias Woodland, 1925 (cestode), three species of nematodes; Procamallanus sp., Capillaria sp. and Philonema onchorhynchi Kuitunen- 
Ekbaum, 1933 and the anthocephalan Polymorphus sp. Among these identified parasitic groups the nematodes were the commonest discovered parasites $(49.12 \%)$. The infection rates by the other helminth groups were $(31.57 \% ; 19.3 \% \& 15.8 \%)$ for cestode, trematode and acanthocephala respectively (Fig. 2). Parasite abundance was 1.73 and total mean intensity was $3.66 \pm 2.49$. The females had more prevalence of infection $(58 \%)$ than males (42\%).

In Clarias gariepinus 22/40 (55\%) samples were infected with 62 of three helminth species; Orientocreadium batrachoides Tubangui, 1931, Procamallanus sp. and Polyonchobothrium clarias Woodland, 1925, with infection intensity of $2.9 \pm 2.89$. Concerning to host's sex, the infection showed higher prevalence in females $(63.15 \%)$ than in males $(47.6 \%)$. Infection rate significantly differed by host sex (Leven's statistics= $1.337, \mathrm{df}=38, \mathrm{P}<0.05$ ). Also, infection was high in hosts with length from $36-45 \mathrm{~cm}$. and large weights. Prevalence did not differ significantly by weight $(\mathrm{t}=13.45, \mathrm{P}>0.05)$. In the present study, infection was highest in spring $(100 \%)$, followed by summer $(80 \%)$ in winter and autumn with equal (20\%). Infection in $C$. gariepinus varied significantly among seasons $\left(\mathrm{K}-\mathrm{W} \chi^{2}=2.561, \mathrm{P} .=0.464\right)$.

In B. bajad fish, $17 / 40$ (42.5\%) were infected by 60 parasites Capillaria sp. and Polymorphus sp. Total mean intensity was $3.53 \pm 1.62$. Females had higher prevalence $(47.3 \%)$ than males $(38 \%)$ with significant difference $($ Leven's statistics $=0.937, \mathrm{df}=38$,
$\mathrm{P}<0.05)$. With regard to the host size, the prevalence was higher in hosts of small and large weights $(\mathrm{P}<0.05)$. The effect of seasonal changes on the infection rate was recorded, it was noticed that the infection reached its highest rate in spring and summer $(60 \%)$ while during winter and autumn it was $(30 \% \& 20 \%)$ respectively. Statistical analysis showed that the intensity of parasites had a significant variation during different seasons $\left(\mathrm{K}-\mathrm{W} \chi^{2}=2.963\right.$, Sig. $\mathrm{P}$. value $=0.397$ ).

In L. niloticus, one nematode, Philonema onchorhynchi Kuitunen-Ekbaum, 1933 was identified with prevalence (45\%). Mean intensity was $4.72 \pm 2.39$. Females were more infected $(48 \%)$ than males $(40 \%)$. Parasitic infection in L. niloticus fish was sex significant dependence on host's sex (Leven's statistics $=0.853, \mathrm{df}=38, \mathrm{P}<0.05)$.

In the present, incidence was higher in hosts of medium sizes and length ranged from $(24-33 \mathrm{~cm})(t=30.448, P>0.05)$. Seasonal changes and their effects on the prevalence by the nematode $P$. onchorhynchi showed that, the parasite reached its highest incidence during summer $(90 \%)$ followed by winter $(50 \%)$ then autumn $(40 \%)$ while no infection was recorded during spring season. No significant differences were observed between the intensity of helminth parasite and seasons through Kruskal-Walis test as it revealed that $\left(\mathrm{K}-\mathrm{W} \chi^{2}=16.878\right.$, Sig. P. val$\mathrm{ue}=0.001$ ).

Details were given in tables $(1,2,3,4,5$, $6,7 \& 8)$ and figures $(1,2 \& 3)$.

Table 1: Prevalence and Mean Intensity of the three fish species

\begin{tabular}{|l|r|r|r|r|r|r|r|c|}
\hline \multirow{2}{*}{ Fish Species } & \multicolumn{2}{|c|}{ No. of examined } & \multicolumn{2}{|c|}{ No. of infected } & \multicolumn{2}{|c|}{ Prevalence \% } & Parasites & Intensity \\
& Male & Female & Male & Female & Male & Female & recovered & mean \pm SD \\
\hline C. gariepinus & 21 & 19 & 10 & 12 & 47.6 & 63.15 & 62 & $2.9 \pm 2.89$ \\
\hline B. bajad & 21 & 19 & 8 & 9 & 38 & 47.3 & 60 & $3.53 \pm 1.62$ \\
\hline L. niloticus & 15 & 25 & 6 & 12 & 40 & 48 & 85 & $4.72 \pm 2.39$ \\
\hline Total & 57 & 63 & 24 & 33 & 42 & 58 & 207 & $3.66 \pm 2.49$ \\
\hline
\end{tabular}

Table 2: Paired Samples Statistics for relation between infection rate by helminthes and C. gariepinus fish weight

\begin{tabular}{|l|c|c|c|c|c|c|c|}
\hline & & Mean & No. & Std. Deviation & Std. Error Mean & Correlation & Significant \\
\hline \multirow{2}{*}{ Pair 1 } & Weight & $3.9095 \mathrm{E} 2$ & 40 & 183.68283 & 29.04281 & .446 & .004 \\
\cline { 2 - 8 } & infection & .55 & 40 & .504 & .080 & & \\
\hline
\end{tabular}


Table 3: Relationship between infection prevalence and length, weight of C. gariepinus fish

\begin{tabular}{|c|c|c|c|c|c|}
\hline Length range cm. & Weight range gm. & No. of hosts & No. of infected & Prevalence \% & Condition factor (K) \\
\hline $21-26(23.5)$ & 165 & 9 & 3 & 33.3 & 1.27 \\
\hline $27-35(31)$ & 350 & 12 & 5 & 41.6 & 1.17 \\
\hline $36-45(40.5)$ & 440 & 12 & 10 & 83.3 & 0.66 \\
\hline $46-53(49.5)$ & 590 & 7 & 4 & 57 & 0.48 \\
\hline
\end{tabular}

Table 4: Paired Samples Statistics for relation between infection rate by helminthes and B. bajad weight

\begin{tabular}{|c|c|c|c|c|c|c|c|}
\hline & & Mean & No. & Std. Deviation & Std. Error Mean & Correlation & Significant \\
\hline \multirow{2}{*}{ Pair 1 } & Weight & $1.866 \mathrm{E} 2$ & 40 & 68.5755 & 10.84274 & -159 & .327 \\
\cline { 2 - 8 } & infection & .4250 & 40 & .50064 & .07916 & & \\
\hline
\end{tabular}

$\mathrm{t}=17.154, \mathrm{df}=39$

Table 5: Relationship between infection rate by helminthes and length, weight of B. bajad fish

\begin{tabular}{|c|c|c|c|c|c|}
\hline Length range cm. & Weight range gm. & No. of hosts & No. of infected & Prevalence \% & Condition factor (ck) \\
\hline $19-25(22)$ & 98.7 & 7 & 5 & 71.4 & 0.009 \\
\hline $26-33(29.5)$ & 170 & 15 & 7 & 46.6 & 0.66 \\
\hline $34-39(36.5)$ & 230 & 14 & 5 & 35.7 & 0.47 \\
\hline $40-45(42.5)$ & 320 & 4 & 0 & 0 & 0.41 \\
\hline
\end{tabular}

Table 6: Paired Samples Statistics for relation between infection rate by helminthes and L. niloticus weight

\begin{tabular}{|l|c|c|c|c|c|c|c|}
\hline & & Mean & No. & Std. Deviation & Std. Error Mean & Correlation & Significant \\
\hline \multirow{2}{*}{ Pair 1 } & Weight & $3.2630 \mathrm{E} 2$ & 40 & 67.63863 & 10.694 & -.087 & .594 \\
\cline { 2 - 8 } & infection & .4500 & 40 & .50383 & .07966 & & \\
\hline
\end{tabular}

$\mathrm{t}=17.154, \mathrm{df}=39$

Table 7: Relationship between infection rate by helminthes and length, weight of L. niloticus fish.

\begin{tabular}{|c|c|c|c|c|c|}
\hline Length range cm. & Weight range gm. & No. of hosts & No. of infected & Prevalence \% & Condition factor (ck) \\
\hline $23-25(24)$ & 202.5 & 6 & 2 & 33.3 & 1.46 \\
\hline $24-33(28.5)$ & 300 & 16 & 11 & 68.75 & 1.29 \\
\hline $31-42(36.5)$ & 387.5 & 18 & 5 & 27.8 & 0.79 \\
\hline
\end{tabular}

Table 8: Relationship between seasonal changes and prevalence (\%), MI (Mean Intensity), M. (Median) and R. (Range) of Helminth Parasites of Fish Species.

\begin{tabular}{|c|c|c|c|c|c|c|c|c|c|c|c|c|c|c|c|c|}
\hline \multirow[b]{2}{*}{ Host } & \multicolumn{16}{|c|}{ Season } \\
\hline & \multicolumn{4}{|c|}{ Summer $(n=10)$} & \multicolumn{4}{|c|}{ Spring $(n=10)$} & \multicolumn{4}{|c|}{ Winter $(n=10)$} & \multicolumn{4}{|c|}{ Autumn $(n=10)$} \\
\hline $\begin{array}{l}\text { C. } \\
\text { gariepinus }\end{array}$ & $\begin{array}{l}\% \\
80\end{array}$ & $\begin{array}{c}\mathrm{MI} \pm \mathrm{SD} \\
1.875 \pm 0.83\end{array}$ & $\begin{array}{r}\text { M. } \\
2.00\end{array}$ & $\begin{array}{c}\mathrm{R} . \\
2\end{array}$ & $\begin{array}{l}\% \\
100\end{array}$ & $\begin{array}{l}\mathrm{MI} \pm \mathrm{SD} \\
4.00 \pm 3.79\end{array}$ & $\begin{array}{r}\text { M. } \\
3.00\end{array}$ & $\begin{array}{c}\mathrm{R} . \\
13\end{array}$ & $\begin{array}{l}\% \\
20\end{array}$ & $\begin{array}{c}\mathrm{MI} \pm \mathrm{SD} \\
1.5 \pm 0.707\end{array}$ & $\begin{array}{l}\text { M. } \\
1.5\end{array}$ & $\begin{array}{r}\mathrm{R} . \\
1\end{array}$ & $\begin{array}{l}\% \\
20\end{array}$ & $\begin{array}{c}\mathrm{MI} \pm \mathrm{SD} \\
2.00 \pm 0.00\end{array}$ & $\begin{array}{l}\text { M. } \\
2.00\end{array}$ & $\begin{array}{l}\mathrm{R} . \\
0.0\end{array}$ \\
\hline $\begin{array}{l}\text { B. } \\
\text { bajad }\end{array}$ & $\begin{array}{l}\% \\
60\end{array}$ & $\begin{array}{c}\mathrm{MI} \pm \mathrm{SD} \\
3.3 \pm 1.966\end{array}$ & $\begin{array}{l}\text { M. } \\
2.5 \\
\end{array}$ & $\begin{array}{r}\mathrm{R} . \\
5\end{array}$ & $\begin{array}{l}\% \\
60 \\
\end{array}$ & $\begin{array}{l}\mathrm{MI} \pm \mathrm{SD} \\
3.0 \pm 1.00 \\
\end{array}$ & $\begin{array}{c}\text { M. } \\
3.00\end{array}$ & $\begin{array}{r}\mathrm{R} . \\
2 \\
\end{array}$ & $\begin{array}{l}\% \\
30 \\
\end{array}$ & $\begin{array}{c}\mathrm{MI} \pm \mathrm{SD} \\
5.33 \pm 1.53\end{array}$ & $\begin{array}{r}\text { M. } \\
5.00 \\
\end{array}$ & $\begin{array}{r}\mathrm{R} . \\
3 \\
\end{array}$ & $\begin{array}{l}\% \\
20 \\
\end{array}$ & $\begin{array}{r}\mathrm{MI} \pm \mathrm{SD} \\
3.5 \pm 0.71 \\
\end{array}$ & $\begin{array}{l}\text { M. } \\
3.5 \\
\end{array}$ & $\begin{array}{c}\mathrm{R} . \\
1\end{array}$ \\
\hline $\begin{array}{l}\text { L. } \quad \text { nilot- } \\
\text { icus }\end{array}$ & $\begin{array}{c}\% \\
90\end{array}$ & $\begin{array}{c}\mathrm{MI} \pm \mathrm{SD} \\
5.55 \pm 2.788\end{array}$ & $\begin{array}{r}\text { M. } \\
5.00\end{array}$ & $\begin{array}{c}\mathrm{R} . \\
9\end{array}$ & $\begin{array}{c}\% \\
0\end{array}$ & $\begin{array}{c}\mathrm{MI} \pm \mathrm{SD} \\
0.0 \pm 0.0\end{array}$ & $\begin{array}{c}\text { M. } \\
0.00\end{array}$ & $\begin{array}{c}\mathrm{R} . \\
0\end{array}$ & $\begin{array}{l}\% \\
50\end{array}$ & $\begin{array}{r}\mathrm{MI} \pm \mathrm{SD} \\
3.8 \pm 1.92\end{array}$ & $\begin{array}{c}\text { M. } \\
4.00\end{array}$ & $\begin{array}{r}\mathrm{R} . \\
5\end{array}$ & $\begin{array}{l}\% \\
40\end{array}$ & $\begin{array}{c}\mathrm{MI} \pm \mathrm{SD} \\
4.00 \pm 1.632\end{array}$ & $\begin{array}{l}\text { M. } \\
4.00\end{array}$ & $\begin{array}{r}\mathrm{R} . \\
4\end{array}$ \\
\hline
\end{tabular}

\section{Discussion}

Fish provides essential source of protein and income for millions of people they account for a small fraction of production and biomass in marine ecosystem (Chai et al, 2005). Fish-borne parasitic zoonoses are diseases that caused by trematodes, nematodes and cestodes. These zoonoses are responsible for a large number of human infections all over the world and have an essential role in the marine ecosystems by affecting population dynamics of their hosts (Rohde, 1993; Chai et al, 2005). Economically, helminthes of fish are very important as they cause a significant damage and pathogenic effects to their hosts including emaciation and hindering growth of fish through absorb a considerable amount of nutritive substances from host's body cause illness or even death (Banerjee et al, 2017). A few authors have been studied the helminthic infection and their abundance from fish at Ismailia Canal. Ibrahim and Soliman (2010) studied the factors that affecting site preference and prevalence of heterophyid metacercariae from Tilapia zilli. Also, Eissa et al. (2010) investigated the helminthes of Oreochromis niloticus at different areas in Ismailia Canal.

Pollutants as well as parasites affect sex hormone levels and the endocrine system of aquatic organisms. Also, they affect hosts' health, occurrence, distribution and increasing the polluted environments, with have an adverse impact on human welfare (Sures, 2001, 2008; Shamrukh and Abdel-Wahab, 
2011). The incidence of some pollutants in Ismailia Canal was studied by Ibrahim et al. (2014) who emphasized that it contains a large amounts of heavy metals which may led to serious concerns through their influence on aquatic life. In the present study, six helminth species were recovered from fish species; Bagrus bajad, Clarias gariepinus and Lates niloticus with total infection rate $(47.5 \%)$. This high incidence might be due to high polluted water.The highest prevalence was in $C$. gariepinus fish $(55 \%)$ infected by trematode, cestode and nematode. C. gariepinus fish is a bottom dweller and feeds on all available food materials including snails' intermediate host (Imevbore and Bakare, 1970). El-Seify et al. (2011) in Kafr-Elsheikh reported (58.6\%) and Aliyu and Solomon (2012) in Lower Usman Dam, Abuja reported (59.38\%), but Edeh and Solomon (2017) in Utako Flowing Gutter reported $(35 \%)$. Prevalence of helminthes in both $B$. bajad and L. niloticus were convergent $(42.5 \%)$ and $(45 \%)$ for each species respectively. These fish species have more resistance to parasitosis than $C$. gariepinus. $B$. bajad fish were previously studied (Mansour et al, 2003) at El-Mansoura, Egypt, ElMansy and Hamada, 2002 \& El-Naggar and Heckmann 2009 at River Nile, Damietta branch). The incidence of infection in $B . b a$ jad is higher than (34\%) that reported by Okpasuo et al. (2016) at Anambra River, Nigeria and is lower than $(97.7 \%)$ recorded by Mansour et al. (2003). In case of $L$. $n i$ loticus fish the incidence of infection recorded in the present study is lower than the prevalences $(86 \%),(52 \%)$ introduced by Mansour et al. (2003) and Al-Bassel (2003) respectively. Among the discovered parasitic species the nematodes Procamallanus sp., Capillaria sp. and Philonema onchorhynchi were the commonest (49.12\%). The second infection was caused by the cestode Polyonchobothrium clarias (31.57\%). Incidences of Orientocreadium batrachoides and Polymorphus sp. were $19.3 \% \& 15.8 \%$ respectively. This difference in the prevalence of infection may be due to the difference of habitats and the amount of available food that contain the intermediate host of these parasites.

The impact of biotic (host's sex \& age) and abiotic factor (seasonal variations) on the intensity of parasite infections in fish have previously been investigated (Sithithaworn et al, 1997, Elsheikha and Elshazly 2008; Ibrahim and Soliman, 2010; Saha et al, 2015). In the present investigation, the infection was higher in females than in males of the three studied fish species with a significant difference in the prevalence between the two sexes. These findings agreed with Gbankoto et al. (2001); Saha et al. (2015) and Edeh and Solomon (2017) who reported that comparatively strong immunity system of males and biochemical changes in quality and quantity of steroid hormone of females and males. This result conflict with that reported by Takemoto and Pavanelli (2000) and Aliyu and Solomon (2012) as they stated that males had significantly higher percentage of infection than females. The difference between the two sexes may be due to the degrees of resistance to parasitic infection as indicated by Emere (2000). Influence of sex on animal susceptibility to infections was attributed to genetic predisposition and differential susceptibility owing to hormonal control (Wali et al, 2016). Similarly, the findings improved a relationship between host size and intensity of infection. The highest prevalence and mean intensity was found in adult $C$. gariepinus fish than juveniles in ones, it could be due to the fact that the fish of larger sizes have a greater surface exposed to infection than smaller one (Bishop and Margolis, 1955). Also, parasite burdens increased in fish of higher lengths and thus size (Roberts, 1978; Aliyu and Solomon, 2012). Roberts (1978) reported that parasitosis increased in older fish. But, the smaller sizes of B. bajad and medium sizes of $L$. niloticus fish were more infected than the larger ones with a significant difference. Sathyanarayana (1982) reported 
that the host size far reached effects on parasitosis. Concerning the condition factor $(\mathrm{K})$ obtained in the present work the infected fish are not healthy. Adeyemo and Falaye (2007) reported that the condition factor measures the well state of the fish.

A definite seasonal impact on the intensity of infection was observed in the present study. The highest percentages of infection in C. gariepinus and B. bajad fish were observed during spring and summer months while the lowest infection was in winter and autumn. Also, the statistical results using Kruskal-Walis test insured that the helminth distribution was varied significantly during these seasons. This agreed with Elsheikha and Elshazly (2008) for Mugil and Tilapia infection in Egyptian brackish water. Ibrahim and Soliman (2010) for Phagicola ascolonga (cestode) from Tilapia zilli at Ismailia Canal and Wali et al. (2016) for acanthocephalan Pomphorhynchus kashmirensis and cestodes Bothriocephalus acheilognathi and Adenoscolex oreini from fish at Dal Lake and River Jhelum, Kashmir. Concerning the seasonal dynamics in L. niloticus it was revealed that the infection by the nematode worm not differed significantly during different seasons. Aydogdu et al. (2015) found that food materials and absence or presence of intermediate hosts were the main causes for parasitic infection. Abundance and intensity of parasites to seasonality were influenced by climatic factors, as well as aquatic fauna and flora and hence fish immune response (Chubb, 1977).

\section{Conclusion}

Studying the zoonotic infectious parasites in freshwater fish in all the Egyptian sea or river costs is a must. The outcome data showed that water pollution markedly affected the two preferable fish to all the populations particularly those living on coastal areas.

\section{References}

Adeyemo, AO, Falaye, AE, 2007: Parasitic incidence in cultured Clarias gariepinus. Ann. Res. Inter. 4, 2:702-4.
Aliyu, MD, Solomon, JR, 2012: The intestinal parasites of Clarias gariepinus found at Lower Usman Dam, Abuja. Res. 4, 9:38-44.

Amin, OM, Heckmann, RA, Radwan, NAE, Anchundia, JSM, Alcivar, MZA, 2009: Redescription of Rhadinorhynchus ornatus (Acanthocephala: Rhadinorhynchidae) from Skipjack Tuna, Katsuwonus pelamis, collected in the Pacific Ocean off South America, with special reference to new morphological features. J. Parasitol. 95, 3:656-64.

Arab Organization for Agricultural Development (AOAD), 2003: Annual Arab Agriculture Statistics Book, Vol. 24.

Aydogdu, A, Emre, N, Emre, Y, 2015: Prevalence and intensity of parasitic helminths of thicklip grey mullet Chelon labrosus in hosts in Beymelek Lagoon lake in Antalya, Turkey, according to season, host size, age, and sex of the host. Turk. J. Zool. 39: 643-51.

Bakare, O, 1970: Bottom deposits as food of inland fresh water fish in Kainji a Nigeria Manmade lake. Vol. I. In: Visser S. A. (Ed). The Nigeria Institute of Social \& Economic Research.

Banerjee, P, Basu, S, Modak, KB, 2017: First report of three metazoan gut parasites of live fishes from West Bengal, India. Proceed. Zool. Soc. DOI 10.1007/s12595-017-0240-0.

Bishop, YMM, Margolis, L, 1955: A statistical examination of Anisakis larvae (Nematoda) in herring (Clupea pallasi) off the British Columbia coast. J. Fish. Res. Bd Can. 12:571-92.

Chai, J, Murrell, KD, Lymbery, AJ, 2005: Fish borne parasitic zoonoses: Status and issues. Int. J. Parasitol. 35:1233-54.

Chubb, JC, 1977: Seasonal occurrence of helminths in freshwater fish. Part I. Monogenea. Adva. Parasitol. 15:133-99.

Debanth, S, 2011: Clarias batrachus, the medicinal fish: An excellent cidate for aquaculture \& employment generation. Inter. Conf. Asia Agriculture and Animal, IPCBEE. 13:32-7.

Edeh, C, Solomon, RJ, 2017: Endoparasites of Oreochromis niloticus and Clarias gariepinus found in Utako flowing gutter. Direct Res. J. Agricult. Food Sci. 4, 12:361-73.

Eissa, IAM, Badran, AF, Sohair, YM, Heba, IA, 2010: Enteric helminthes infections in cultured and wild Oreochromis niloticus in Ismailia province, Egypt. J. Agricul. Vet. Sci. 3, 2:99110. 
El-Bassel, HM, 2003: A general survey of the helminth parasites of fish from inland waters in the Fayoum Governorate, Egypt. Parasitol. Res. 90, 2:135-9.

El-Mansy, IA, Hamada, FS, 2002: Histopathological study of Bagrus bayad and Clarias gariepinus from Damietta Nile branch infested with three digenean parasites. Egypt. J. Aqua. Biol. Fisher. 6, 4: 165-82.

El-Naggar, AM, Heckmann, RA, 2009: HostParasite interaction of helminths infecting the intestine of Bagrus bayad (Forshal, 1775), from River Nile, Egypt. Proceed. Parasitol. 47:61-73.

El-Nwishy, NM, Ahmed, M, El-Sherif, M, Abd El-Hameed, M, 2007: The effect of diazinon on glutathione and acetylecholinesterase in tilapia (Oreochromis niloticus). J. Agricul. Soc. Sci. 3:52-4.

El-Seify, AM, Mona, ZS, Abdel Razek, DY, Hossam, AH, Osman, AK, et al, 2011: Seasonal variations and prevalence of some external parasites affecting freshwater fishes reared at Upper Egypt. Life Sci. J. 8, 3:397-400.

Elsheikha, HM, El-Shazly, AM, 2008: HostDependent variations in the seasonal prevalence and intensity of Heterophyid encysted metacercariae (Digenea: Heterophyidae) in brackish water fish in Egypt. Vet. Parasitol. 153, 1/2:65-72.

Emere, MC, 2000: Parasitic infection of the Nile Perch (Lates niloticus) in River Kaduna. J. Aqua. Sci. 31: 34-45.

Gbankoto, A, Pampoulie, C, Marques, A, Sakiti, GN, 2001: Occurrence of myxosporean parasites in the gills of two Tilapia species from Lake Nokoué (Bénin, West Africa): effect of host size and sex, and seasonal patterns of infection. Dis. Aqua. Org. 44:217-22.

Geriesh, HM, Balke, K, El-Bayes, A, 2008: Problems of drinking water treatment along Ismailia Canal Province, Egypt. J. Zhejiang Univ. Sci. B., 9, 3:232-42

Gibson, D.I, Jones, A, Bray, RA, 2002: Keys to the Trematode Volume I, CABI Publishing and the Natural History Museum, London, United Kingdom.

Ibrahim, MM, Soliman, MFM, 2010: Prevalence and site preferences of Heterophyid metacercariae in Tilapia zilli from Ismailia freshwater canal, Egypt. Parasit. 17: 233-9.

Ibrahim, SH, Ibrahim, AM, Samhan, AF, 2009: Distribution and bacterial bioavailability of selected metals in sediments of Ismailia Canal, Egypt. J. Hazard. Mater. 168:1012-6.
Ibrahim, SS, Bakery, HH, EL-Shawarby, R M, Abuo Salem, ME, Nabila, MA, 2014: Incidence of some pollutants in Ismailia Canal and using different methods for removal. Benha Vet. Med. J. 27, 1:62-77.

Imevbore, AMA, Bakare, O, 1970: The food and feeding habits of the catfishes Chrisichthys walkeri (Gunther), C. filamentosus (Boulenger) and $C$. nigrodigitatus (Lacepede) in Lekki Lagoon, Nigeria. J. Fish Biol.10: 105-15.

Khanum, H, Easmin, F, Hasan, SM, Zaman, FR, 2015: Helminth and parasitic arthropod prevalence in catfish Clarias batrachus (L.) from ponds in Savar. Bangladesh J. Zool. 43, 2:26977.

Mansour, AFM, Hassan, HS, Khidr, AA, Ghanem, AM, 2003: General survey on certain helminth parasites infecting some Nile fishes at El-Mansoura, Egypt. Egypt. J. Aqua. Biol. Fisher. 7, 4:423-46.

Margolis, L., Esch, WG, Holmes, CJ, Kuris, MA, Shad, AG, 1982: The use of ecological terms in parasitology (Report of the Committee of the American Society of Parasitologists). J. Parasitol. 68:131-3

Okpasuo, JO, Ezenwaji, EN, Onah, EL, Ekeh, NF, Ngwu, LG, 2016: Parasites of freshwater and condition factor of Bagrid fishes in Anambra River Basin, Nigeria. Inter. J. Pharm. Biol. Sci. 6, 4:13-26.

Roberts, RJ, 1978: Isolation and identification of parasite organisms. Fish Pathol. 2: 209-19.

Rohde, K, 1993: Ecology of Marine Parasites: An Introduction to Marine Parasitology. $2^{\text {nd }}$ ed. Wallingford: CAB International.

Sabri D, Eissa MAI, Danasoury AM, Khouraiba MH, 2010: Prevalence of Henneguya branchialis in Catfish (Clarias gariepinus) in Ismailia, Egypt. Inter. J. Agricul. Biol. 12:897-900.

Saha, M, Bandyopadhyay, KP, Roy, A, Ghosh, S, 2015: Impact of seasons, host age, size and sex on prevalence of protozoan parasites in ornamental fish. J. Agricul. Vet. Sci. 8, 10:54-9.

Sathyanarayana, MC, 1982: Incidence of trematode parasite, Paraplerurus sauridae, in relation to season, sex and length of the marine fish, Saurida undosquamis. J. Mari. Sci.11:188-9.

Schultz, K, 2003: Field Guide to Freshwater Fish. Published by Wiley. $1^{\text {st }}$ edition.

Shamrukh, M, Abdel-Wahab, A, 2011: Chapter 2 Water pollution and Riverbank filtration for water supply along River Nile, Egypt. DOI 10.1007/978-94-007-0026-0_2, 
Sithithaworn, P, Pipitgool, V, Srisawangwong, T, Elkins, DB, Haswell-Elkins, MR, 1997: Seasonal variation of Opisthorchis viverrini infection in cyprinoid fish in north-east Thailand: implications for parasite control and food safety. Bull. WHO75:125-31.

Stahl, R, Ramadan, A, 2008: Environmental studies on water quality of the Ismailia Canal, Egypt. Forschungszentrum Karlsruhe GmbH, Postfach 3640, 76021 Karlsruhe, ISSN 0947-8620.

Stoskoff, KM, 1992: Fish Medicine. W.B. Saunders Company, Philadelphia 882 pp.

Sures, B, 2001: The use of fish parasites as bioindicators of heavy metals in aquatic ecosystems, a review. Netherlands Aqua. Biol. 35:245-55.

Sures, B, 2008: Host-parasite interactions in polluted environments. J. Fish Biol. 73, 9:2133-42.

Takemoto, MR, Pavanelli, CG, 2000: Aspects of ecology of proteocephalid cestodes parasites of Sorubim lima (Pimelodidae) of the upper Paraná River, Brazil. I. Structure and influence of host's size and sex. Brazil. J. Biol. 60, 4:577-84. Wali, A, Balkhi, HM, Maqbool, R, Darzi, M M, Shah, AF, et al, 2016: Distribution of helminth parasites in intestines and their seasonal rate of infestation in three freshwater fishes of Kashmir. J. Parasitol. Res. 16: 8901518.

Yamaguti, S, 1958: Systema Helmintum, the digenetic trematodes of vertebrates. Vol. I part I. II Interscience Publishers, New York.

Yamaguti, S, 1961a: Systema Helmintum, the nematodes of vertebrates. Interscience Publishers, New York and London.

Yamaguti, S, 1961b: Acanthocephala Systema Helmintum, Interscience Publishers, New York and London.

Yanong, ER, 2017: Nematode (Roundworm) infections in fish: Tropical Aquaculture Laboratory, Program in Fisheries and Aquatic Sciences, School of Forest Resources and Conservation, UF/IFAS Extension, Gainesville, FL 32611. http://edis.ifas.ufl.edu.

\section{Explanation of figures}

Fig. 1: A map showing position of Ismailia Canal, Latitude, 30, 0667 N; Longitude, 31,2667; Altitude, $10 \mathrm{~m}$ above sea level. Fig. 2: Prevalence of infection in different helminth groups in the studied hosts

Fig. 3: Prevalence of infection according to the sex of the host

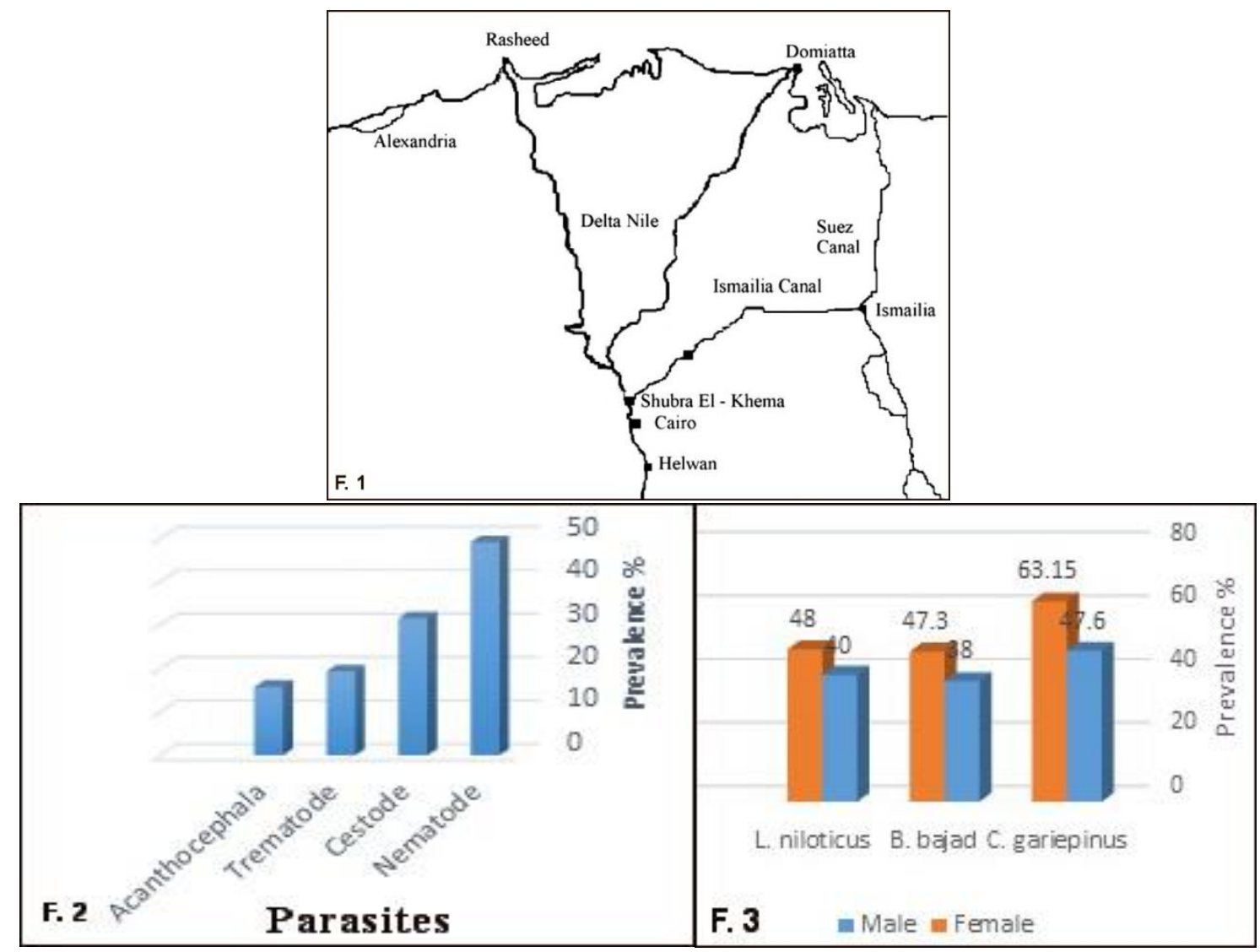

